\title{
THE BOND STRENGTH OF DENTAL PORCELAIN TO COBALT-CHROMIUM ALLOYS FABRICATED BY CASTING, MILLING AND BY SELECTIVE LASER MELTING: A COMPARATIVE ANALYSIS
}

\author{
PRIMERJALNA ANALIZA OPRIJEMA DENTALNEGA \\ PORCELANA NA ULITO, REZKANO IN SELEKTIVNO LASERSKO \\ TALJENO ZLITINO KOBALT-KROMA
}

\author{
Maja Antanasova ${ }^{1,2}$, Andraž Kocjan², Borut Žužek ${ }^{3}$, Sašo Jovanovski ${ }^{4}$, \\ Peter Jevnikar ${ }^{1 *}$ \\ ${ }^{1}$ University of Ljubljana, Faculty of Medicine, Department of Prosthodontics, Hrvatski trg 6, 1000 Ljubljana, Slovenia \\ 2Jožef Stefan Institute, Department for Nanostructured Materials, Jamova 39, 1000 Ljubljana, Slovenia \\ ${ }^{3}$ Institute of Metals and Technology, Lepi pot 11, 1000 Ljubljana, Slovenia \\ ${ }^{4}$ University Ss Cyril and Methodius, Faculty of Dentistry, Department of Prosthodontics, Majka Tereza 43, 1000 Skopje, Macedonia
}

Prejem rokopisa - received: 2019-05-06; sprejem za objavo - accepted for publication: 2019-06-27

doi:10.17222/mit.2019.095

This study was set up to explore the effects of the applied routes for fabricating cobalt-chromium (Co-Cr) dental frameworks on the metal-ceramic bond strength. Three groups $(n=12$ /group) of Co-Cr specimens $(25 \times 3 \times 0.5)$ mm were fabricated by casting, milling, and by selective laser melting (SLM), and then airborne-particle abraded $\left(110 \mu \mathrm{m} \mathrm{Al}_{2} \mathrm{O}_{3}\right.$ particles). Dental porcelain was applied $(8 \times 3 \times 1.1) \mathrm{mm}$ onto the $\mathrm{Co}-\mathrm{Cr}$ substrates, and the metal-ceramic bond strength was assessed by a three-point bend test according to the ISO 9693-1:2012 standard. Failure modes were determined using stereomicroscopy. Representative specimens from each group were used to assess the element distribution across the metal-ceramic interface, together with an inspection of its microstructure using a scanning electron microscope (SEM) and energy-dispersive spectroscopy (EDS). Average profile roughness $\left(R_{\mathrm{a}}\right)$ values were obtained for each group of metal substrates. The metal-ceramic bond strength data and $R_{\mathrm{a}}$ data were statistically analyzed (one-way ANOVA, Tukey's HSD test, $\alpha=0.05$ ). The mean surface roughness was affected by the fabrication technology $(p<0.01)$, SLM Co-Cr demonstrating a significantly higher $R_{\mathrm{a}}$ value $(1.78 \pm 0.20 \mu \mathrm{m})$, than cast and milled $\mathrm{Co}-\mathrm{Cr}(1.21 \pm 0.07 \mu \mathrm{m}$ and $1.05 \pm 0.11 \mu \mathrm{m}$ respectively). However, the metal processing applied did not affect the metal-ceramic bond $(p=0.104)$. Differently processed metal-ceramic specimens showed a comparable distribution of elements on the interface, together with good wetting between the alloy and the porcelain. The porcelain bond strengths to cast, milled and SLM Co-Cr alloys are well above the minimum ISO 9693-1:2012 recommended value of $25 \mathrm{MPa}$ for metal-ceramic systems, thus allowing the clinical application of SLM Co-Cr in porcelain-fused-to-metal prostheses.

Keywords: prosthetic dentistry, selective laser melting, metal-ceramic, bond strength

Preučevali smo vpliv tehnologije izdelave $\mathrm{Co}-\mathrm{Cr}$ dentalnih ogrodij na oprijem porcelana. Z ulivanjem, rezkanjem in selektivnim laserskim taljenjem (SLT) smo izdelali 3 skupine $\left(n=12 /\right.$ skupino) Co-Cr vzorcev $\left(25 \times 3 \times 0.5 \mathrm{~mm}^{3}\right)$ in jih peskali s $110 \mu \mathrm{m}$ zrni $\mathrm{Al}_{2} \mathrm{O}_{3}$. Na peskane površine smo nanesli nizkotaljiv dentalni porcelan $\left(8 \times 3 \times 1.1 \mathrm{~mm}^{3}\right)$. Trdnost kovinsko-porcelanskega spoja smo določili s tritočkovnim upogibnim preizkusom v skladu s standardom ISO 9693-1:2012. Lomne površine smo analizirali s svetlobnim mikroskopom. Analizirali smo tudi kovinsko-porcelanske stične površine. Morfologijo smo preučevali z vrstičnim elektronskim mikroskopom (VEM), kemijsko sestavo pa z energijsko-disperzijsko spektrometrijo (EDS). Reprezentativne kovinske vzorce iz vsake skupine smo uporabili za določanje povprečne hrapavosti $\left(R_{\mathrm{a}}\right)$. Dobljene vrednosti oprijema porcelana/hrapavosti smo analizirali z ANOVA in post hock testi $(\alpha=0.05)$. Povprečna hrapavost je bila odvisna od načina izdelave zlitine $(p<0.01)$. SLT Co-Cr je imel najvišjo $R_{\mathrm{a}}$ vrednost $(1.78 \pm 0.20 \mu \mathrm{m})$ med testiranimi kovinami. Pri ulitih in rezkanih Co-Cr zlitinah sta izmerjeni $R_{\mathrm{a}}$ vrednosti znašali $1.21 \pm 0.07 \mu \mathrm{m}$ in $1.05 \pm 0.11 \mu \mathrm{m}$. Tehnologija izdelave Co-Cr zlitine ni značilno vplivala na oprijem dentalnega porcelana $(p=0.104)$. Različno izdelani kovinsko-porcelanski vzorci so pokazali primerljivo razporeditev elementov na kovinsko-porcelanski stični površini. Trdnost vezave dentalnega porcelana na ulito, rezkano in selektivno lasersko taljeno zlitino Co-Cr je bila precej nad najnižjo ISO 9693-1:2012 priporočeno vrednostjo za kovinsko-porcelanske sisteme $(25 \mathrm{MPa})$. SLT tehnologija se je izkazala ustrezna za izdelavo kovinsko-porcelanskih protetičnih sider.

Ključne besede: stomatološka protetika, selektivno lasersko taljenje, kovinsko-porcelanska sidra, trdnost vezave

\section{INTRODUCTION}

Porcelain-fused-to-metal (PFM) dental prostheses combine the good mechanical properties of the metal framework and favorable aesthetics of veneered porcelain. In certain clinical situations, particularly when

*Corresponding author's e-mail:

peter.jevnikar@mf.uni-lj.si (Peter Jevnikar) extensive fixed dental prostheses (FDPs) are planned, the PFM concept represents the most reliable restorative choice, validated by favorable long-term clinical outcomes. $^{1}$

A range of noble and base dental alloys are used in PFM prostheses, but the increasing cost of noble metals, together with the high allergenic potential of nickelchromium alloys, have led to the wide acceptance of the 
cobalt-chromium (Co-Cr) alloys as the materials of choice for fabricating PFM prostheses., ${ }^{2,3}$ Metal frameworks in PFM prostheses have, traditionally, been fabricated by lost-wax casting. The casting technique, however, is time consuming and can often be challenging due to the high melting range of the various metals and their susceptibility to oxidation at high temperatures. ${ }^{4}$ Computer-aided design/computer-aided manufacturing (CAD/CAM) has enabled the implementation of advanced routes for metal processing as an alternative to the traditional lost-wax casting. 5,6 The metal frameworks are designed by CAD and then fabricated by either subtractive or additive CAM processes. With the subtractive method, the process of computer numerical controlled (CNC) milling is used to fabricate metal frameworks from solid prefabricated blocks of material. This approach is applied successfully for the fabrication of dental restorations from a wide variety of materials but has a limited potential for obtaining complex shapes and results in a substantial waste of material. ${ }^{7}$ In order to overcome these shortcomings, an additive approach to fabricating metal frameworks has recently been introduced. Selective laser melting (SLM) is an additive manufacturing (AM) technology that is based on the laser fusion of multiple layers of powder material into a three-dimensional restoration. The respective layers correspond to the virtual cross-sections of the CAD model. There is almost no material waste since the remaining powder can be used for subsequent SLM. ${ }^{5}$

With the recent technological advances and their implementation in prosthetic dentistry for the fabrication of PFM FDPs, differences in the clinical behavior of differently processed metal frameworks can be anticipated. ${ }^{8}$ Adequate metal-ceramic bonding plays an important role in the clinical reliability of the PFM prostheses. ${ }^{1}$ It has been shown that four mechanisms contribute to the metal-ceramic bonding: chemical bonding, mechanical interlocking, van der Waal's interactions, and compressive forces. ${ }^{9}$ The presence of an oxide layer on the metal surface has been considered to be essential for establishing a chemical bond between the metal framework and the ceramics. Namely, the porcelain dissolves away the metal oxide originally formed during the firing cycle and becomes saturated with oxides of the underlying alloy, thus allowing chemical interaction between the metal and the ceramics. ${ }^{10,11}$ Mechanical bonding occurs due to mechanical interlocking on the metal-porcelain interface. Van der Waal's forces imply attraction based on atom-atom interactions with no chemical bond taking place. ${ }^{12,13}$ The porcelain has a slightly lower coefficient of thermal expansion (CTE) than the metal and is thus exposed to residual compression on cooling from the firing temperatures. This contributes to more reliable metal-ceramic bonding. ${ }^{14}$

Since the chemical bond between the porcelain and the metal is established through the surface oxides of the latter, the oxidation behavior of the alloy appears to be essential for the reliability of the PFM FDPs. The oxidation rate of the metal framework is affected by the composition and the microstructure of the alloy. ${ }^{15}$ Elements comprising the dental alloys exhibit diverse affinities for oxygen and even the slightest compositional differences could affect the overall oxidation rate of the alloy and thus the chemical bond between the metal and the porcelain. ${ }^{16,17}$ Nevertheless, in most of the studies to date, exploring the differences in the strength of porcelain bonds to Co-Cr alloys fabricated by different technologies, there were compositional differences between the tested alloys. ${ }^{18-24}$ This is probably due to material limitations and the tendency of the manufacturers to slightly modify the composition of the alloys that are to be processed through different technological procedures. In addition, F. Pitt and M. Ramulu ${ }^{15}$ showed that a fine metal microstructure exhibits more rapid oxidation kinetics than does a coarser microstructure. Variations in the microstructure and mechanical properties between differently processed alloys have been shown to exist and this could affect the metal-ceramic bond. ${ }^{8,18,25,26}$ Furthermore, variations in surface texture have been reported ${ }^{19,20}$ that could affect the mechanical interlocking between the metal and the ceramics.

The present study was set up to explore the effect of varied $\mathrm{Co}-\mathrm{Cr}$ fabrication on the metal-ceramic bond strength. The first null hypothesis was that varied $\mathrm{Co}-\mathrm{Cr}$ fabrication would not affect the metal-ceramic bond strength. In order to eliminate the influence of the chemical composition, the metal substrates were fabricated from the same Co-Cr alloy by casting, milling and SLM. Also, the effect of the fabrication technology on the roughness of the metal substrates was examined. The second null hypothesis was that the varied fabrication of Co-Cr would not affect its surface roughness following airborne-particle abrasion.

\section{EXPERIMENTAL PART}

A total of $36 \mathrm{Co}-\mathrm{Cr}$ substrates were fabricated by casting, CNC milling and by SLM. The Co-Cr substrates were divided into three groups ( $n=12 /$ group) according to the applied technology for metal processing. The groups and materials used in this study are presented in Table 1.

The conventional lost-wax technique was used to cast one group (C group) of specimens in Co-Cr. Smooth wax-sheets (BEGO GmbH \& Co. KG), $0.5 \mathrm{~mm}$ in thickness, served as the casting templates. The wax sheets were tailored according to the dimensions $(25 \times 3 \times 0.5)$ $\mathrm{mm}$ specified in the International Organization for Standardization (ISO) standard 9693-1:2012 ${ }^{27}$, mounted in silicone rings and embedded in a refractory phosphate-bonded investment (Fujivest; GC Corp.). The rings were then heated in a furnace to evaporate the wax and 
Table 1: Specification of groups and materials used in this study

\begin{tabular}{|c|c|c|c|c|c|c|c|}
\hline Group & Brand name & Material type & $\begin{array}{c}\text { General composition } \\
(w / \%)^{\mathrm{a}}\end{array}$ & $\begin{array}{c}\mathrm{CTE}^{\mathrm{a}, \mathrm{b}} \\
\left(\times 10^{-6} \mathrm{~K}^{-1}\right)\end{array}$ & $\begin{array}{c}E_{\mathrm{M}} \\
(\mathrm{GPa})^{\mathrm{a}} \\
\end{array}$ & Manufacturer & $\begin{array}{l}\text { Batch } \\
\text { number }\end{array}$ \\
\hline $\mathrm{C}$ & $\underset{\text { star }}{\text { Remanium }}$ & $\begin{array}{l}\text { Metal ingots: } \\
\text { Casting }\end{array}$ & $\begin{array}{c}\text { Co } 60.5 \%, \text { Cr } 28 \%, \mathrm{~W} 9 \%, \mathrm{Si} \\
1.5 \%, \text { Other }(\mathrm{Mn}, \mathrm{N}, \mathrm{Nb}, \mathrm{Fe}) \\
<1 \%\end{array}$ & 14.1 & 190 & $\begin{array}{l}\text { Dentaurum GmbH } \\
\quad \& \text { Co. KG }\end{array}$ & 1010 \\
\hline M & $\begin{array}{l}\text { Remanium } \\
\text { star MD I }\end{array}$ & $\begin{array}{l}\text { Metal blank: } \\
\text { Milling }\end{array}$ & $\begin{array}{c}\text { Co } 60.5 \%, \text { Cr } 28 \%, \mathrm{~W} 9 \%, \mathrm{Si} \\
1.5 \%, \text { Other }(\mathrm{Mn}, \mathrm{N}, \mathrm{Nb}, \mathrm{Fe}) \\
<1 \%\end{array}$ & 14.1 & 230 & $\begin{array}{c}\text { Dentaurum GmbH } \\
\text { \& Co. KG }\end{array}$ & 408699 \\
\hline \multirow[t]{2}{*}{$\mathrm{S}$} & $\begin{array}{c}\text { Remanium } \\
\text { star CL }\end{array}$ & $\begin{array}{c}\text { Metal powder } \\
(\text { particle size } \\
10-30 \mu \mathrm{m}): \text { SLM }\end{array}$ & $\begin{array}{c}\text { Co } 60.5 \%, \text { Cr } 28 \%, \mathrm{~W} 9 \%, \mathrm{Si} \\
1.5 \%, \text { Other }(\mathrm{Mn}, \mathrm{N}, \mathrm{Nb}, \mathrm{Fe}) \\
<1 \%\end{array}$ & 14.1 & 230 & $\begin{array}{l}\text { Dentaurum GmbH } \\
\quad \& \text { Co. KG }\end{array}$ & 463368A \\
\hline & $\begin{array}{c}\text { VITA VMK } \\
\text { Master }\end{array}$ & $\begin{array}{l}\text { Dental ceramics: } \\
\text { low-fusing } \\
\left(850-1100^{\circ} \mathrm{C}\right)\end{array}$ & Glass (silica) based ceramics & $13.2-14$ & N/A & $\begin{array}{l}\text { VITA Zahnfabrik } \\
\text { GmbH \& Co. KG }\end{array}$ & $\begin{array}{l}54230 \\
52100 \\
59370 \\
46450\end{array}$ \\
\hline
\end{tabular}

Abbreviations: CTE - Coefficient of thermal expansion, $E_{\mathrm{M}}$ - Young's modulus of elasticity, SLM - selective laser melting, N/A - not available, ${ }^{\mathrm{a}}$ As provided by the manufacturer, ${ }^{\mathrm{b}} \mathrm{In}$ the range $25-500{ }^{\circ} \mathrm{C}$

the molds placed in a centrifugal casting unit (Ducatron S3 Prisma; Ugin'Dentaire) for Co-Cr casing.

Rectangular CAD models $(25 \times 3 \times 0.5) \mathrm{mm}$ were designed for subtractive CNC milling and additive SLM. One group of specimens (M group) was designed in Exocad Dental Cad software (Exocad GmbH) and then milled (Arrow Mill Beluga; Dentas LLC) from prefabricated Co-Cr blanks. In addition, the SLM technology LaserCusing (Concept Laser $\mathrm{GmbH}$ ) was used to fabricate one group ( $\mathrm{S}$ group) of $\mathrm{Co}-\mathrm{Cr}$ specimens. The CAD model was designed in Solidworks CAD software (Dassault Systemes SE) and transferred to the CAM unit (Mlab-R; Concept Laser GmbH) where SLM was carried out in an atmosphere of argon, using a laser energy density $(E D)$ of $1.898 \mathrm{~J} / \mathrm{mm}^{2}$. $E D$ is a function of the laser power $P(\mathrm{~W})$, the scan speed $V(\mathrm{~mm} / \mathrm{s})$ and the spacing between the scan lines $S(\mathrm{~mm})^{26}$, and is defined by the Equation (1):

$$
E D=P / V S
$$

The specimens were aligned on the building platform with their 3-mm-wide edge parallel to the $\mathrm{z}$-axis and the layer thickness was set to $25 \mu \mathrm{m}$. The SLM substrates were then subjected to heat treatment in accordance with the powder manufacturer's recommendations.

Representative CAM metal specimens remained intact. They were used to determine the average profile roughness $\left(R_{\mathrm{a}}\right)$ following CNC milling and SLM, while the cast specimens had to be airborne-particle abraded in order to remove the investment material from their surface. The cast substrates together with the remaining CNC milled and SLM substrates were airborne-particle abraded with $110-\mu \mathrm{m} \mathrm{Al}_{2} \mathrm{O}_{3}$ powder (Korox; BEGO $\mathrm{GmbH} \& \mathrm{Co} . \mathrm{KG}$ ) for 10 seconds, under 0.2-MPa pressure, and at an angle of 45 degrees. The abraded $\mathrm{Co}-\mathrm{Cr}$ specimens were then cleaned with steam and allowed to dry. Metal substrates, selected at random from each group, were used to characterize the surface texture. $R_{\mathrm{a}}$ was determined from three readings per group, $3 \mathrm{~mm}$ in length each (contact profilometer Talysurf 10; Taylor Hobson Ltd.). Also, surface texture and roughness averages $\left(S_{\mathrm{a}}\right)$ over areas of $1.3 \mathrm{~mm}^{2}$ each were recorded using 3D focus-variation microscopy (Alicona InfiniteFocus; Alicona Imaging $\mathrm{GmbH}$ ).

A conventional low-fusing feldspathic porcelain (VITA VMK Master; VITA Zahnfabrik GmbH \& Co. $\mathrm{KG})$ was applied over an $8 \mathrm{~mm}$ length, $3 \mathrm{~mm}$ width and $1.1 \mathrm{~mm}$ thickness at the center of each $\mathrm{Co}-\mathrm{Cr}$ specimen, complying with ISO 9693-1:2012 specifications (Fig-
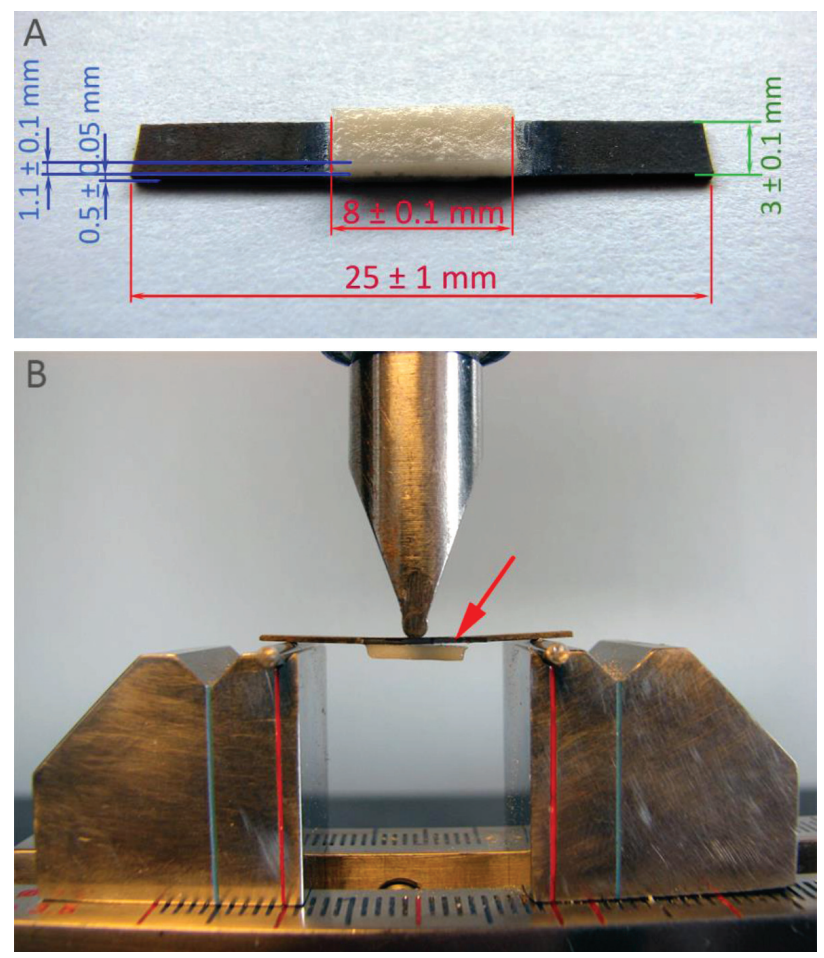

Figure 1: Assessing of the strength of the metal-ceramic bond in accordance with ISO 9693-1:2012 standard: a) metal-ceramic test specimen, b) three-point bending test; the arrow points to the location of the debonding crack 
ure 1a). ${ }^{27}$ A specially designed stainless-steel jig was used to apply a thin layer of wash opaque paste onto the Co-Cr substrates, followed by the application of opaque porcelain, two dentin porcelain layers, and a glaze layer. The respective layers were fired in a porcelain furnace (Vita Vacumat 6000M furnace; VITA Zahnfabrik GmbH \& Co. KG) in accordance with the firing schedules recommended by the porcelain manufacturer.

The metal-ceramic bond strength was assessed with the Schwickerath crack-initiation three-point bending test, as recommended in ISO 9693-1:2012.27 Specimens were placed on supports with a span distance of $20 \mathrm{~mm}$, then loaded with a bending piston $(2 \mathrm{~mm}$ in diameter) at a crosshead speed of $1.5 \mathrm{~mm} /$ minute into a universal testing machine (Instron 4301; Instron Corp.) until a debonding crack appeared. The specimen orientation on the bending apparatus - with the porcelain positioned symmetrically on the side opposite the applied load - is shown in Figure 1b. The debonding load $(F)$ expressed in newtons $(\mathrm{N})$ was recorded as the maximum load before a sharp drop in the plot of load vs deflection. The flexural bond strength (in MPa) was calculated according to Equation (2):

$$
\tau b=F \times k
$$

The value of $k$ was determined as a function of the thickness $(0.5 \pm 0.05 \mathrm{~mm})$ and the elastic modulus of the metal substrate, according to a diagram presented in ISO 9693-1:2012. The values of the Young's modulus of elasticity for the cast, CNC milled, and SLM Co-Cr substrates are shown in Table 1. The modes of failure were determined macroscopically and under a stereomicroscope (Stereo Discovery V8; Carl Zeiss Microscopy $\mathrm{GmbH})$.

Metal-ceramic specimens, selected at random from each group, were embedded in acrylic resin (VersoCit 2 kit; Struers Inc.) and then ground and polished (LaboPol-5; Struers Inc.) to expose the metal-ceramic boundary. The morphology and the element distribution across the metal-ceramic interface were assessed using field-emission scanning electron microscopy (FE-SEM) (Jeol JSM-7600F; Jeol Ltd.) and energy-dispersive spectroscopy (EDS) line scans, $22 \mu \mathrm{m}$ in length each, operating at $15 \mathrm{~mm}$ working distance and $15 \mathrm{kV}$.

The metal-ceramic bond data and the $R_{\mathrm{a}}$ data were analyzed statistically (SPSS Statistics v. 22 software;
IBM Corp.). Shapiro-Wilk and Levene tests were performed to assess the assumptions of normality of the data and homogeneity of variances. The effect of fabrication (independent factor) on the bond strength (dependent variable) was determined with one-way analysis of variance (ANOVA), followed by Tukey's HSD post hock test. The effect of fabrication (independent factor) on the roughness (dependent variable) was determined with one-way ANOVA, followed by Tukey's HSD post hock test. The significance level was set at $\alpha=$ 0.05 .

\section{RESULTS}

The $R_{\mathrm{a}}$ values obtained for each group of airborneparticle abraded Co-Cr substrates are presented in Table 2. One-way ANOVA for the $R_{\mathrm{a}}$ data revealed that the mean surface roughness following airborne-particle abrasion is affected by the fabrication technology $\left(F_{(2,6)}\right.$ $=24.038, p<0.01)$, SLM Co-Cr demonstrating a significantly higher $R_{\mathrm{a}}$ value than cast and milled Co-Cr. The difference in roughness was even more pronounced between the Co-Cr substrates, which remained intact following the SLM and CNC milling, showing $R_{\mathrm{a}}$ values of $3.55 \pm 0.29 \mu \mathrm{m}$ and $0.40 \pm 0.03 \mu \mathrm{m}$ respectively.

Surface textures and $S_{\mathrm{a}}$ values for the cast, milled and SLM Co-Cr substrates following airborne-particle abrasion are presented in Figure 2. The 3D focus variation microscopy recorded similar surface textures, with more pronounced roughness of the SLM substrates.

However, the metal processing applied did not appear to influence the metal-ceramic bond $\left(F_{(2,27)}=2.461, p=\right.$ $0.104)$. The mean bond-strength values and standard deviations for each group are presented in Table 2. The failure modes are presented in Figure $\mathbf{3}$ and their distribution throughout the groups is summarized in Table 2.

SEM micrographs, together with EDS line profiles of representative $\mathrm{Co}-\mathrm{Cr}$-ceramic interfaces, are presented in Figure 4. Good wetting and contact between the porcelain and all the Co-Cr alloys were recorded. Differently processed metal-ceramic specimens showed a comparable distribution of elements on the interface. The EDS profiles showed a gradual transition of the elements comprising the alloy and the porcelain, with the intensity of the $\mathrm{Co}$ and $\mathrm{Cr}$ signals being reduced towards the cera-

Table 2: Mean values and standard deviations for the surface roughness $\left(R_{\mathrm{a}}\right)$ and the metal-ceramic bond strength of the test groups, together with failure mode distribution throughout the groups

\begin{tabular}{|c|c|c|c|c|c|c|}
\hline \multirow{2}{*}{ Group } & \multirow{2}{*}{ Metal substrate } & \multirow{2}{*}{$\begin{array}{c}R_{\mathrm{a}}(\mu \mathrm{m}), \\
n=3 / \text { group }\end{array}$} & $\begin{array}{c}\text { Bond strength } \\
(\mathrm{MPa}), \\
n=10 / \text { group }\end{array}$ & \multicolumn{3}{|c|}{ Failure mode $n(\%)$} \\
\cline { 3 - 7 } & Cast Co-Cr & $1.21 \pm 0.07^{\mathrm{A}}$ & $50.61 \pm 5.30^{\mathrm{a}}$ & $10(100)$ & $0(0)$ & 0 \\
\hline $\mathrm{C}$ & Milled Co-Cr & $1.05 \pm 0.11^{\mathrm{A}}$ & $45.54 \pm 6.07^{\mathrm{a}}$ & $10(100)$ & $0(0)$ & 0 \\
\hline $\mathrm{M}$ & SLM Co-Cr & $1.78 \pm 0.20^{\mathbf{B}}$ & $49.46 \pm 4.61^{\mathrm{a}}$ & $7(70)$ & $0(0)$ \\
\hline $\mathrm{S}$ & &
\end{tabular}

Values marked with the same letters in the column do not differ significantly from each other (Tukey's HSD test, $\alpha=0.05$ ),

$n$ - number of specimens, $\%$ - percentages for each fracture mode are presented in brackets 

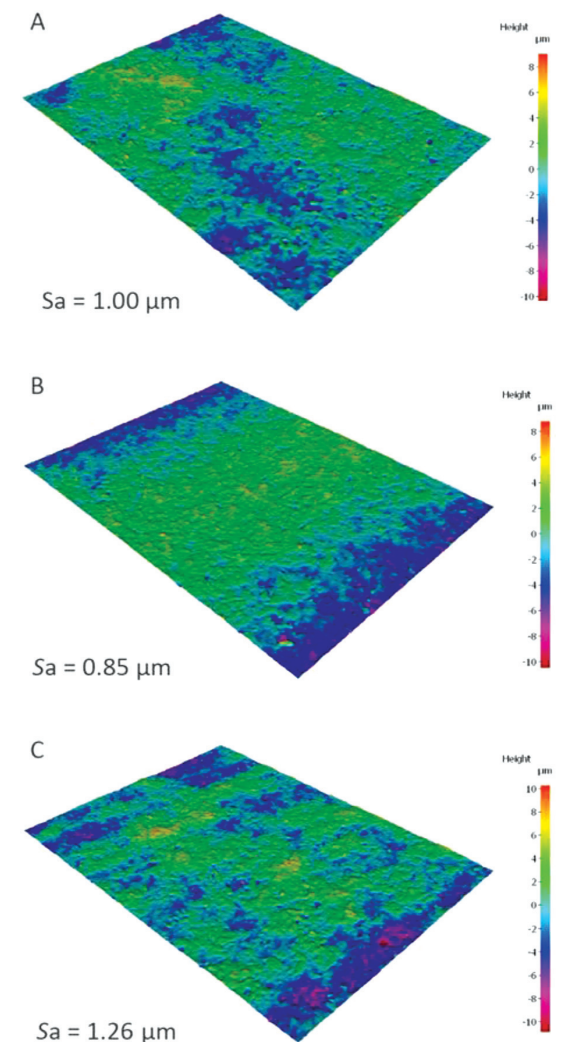

Figure 2: Surface textures and $S_{\mathrm{a}}$ values following airborne-particle abrasion of Co-Cr specimens fabricated by: a) casting, b) milling, c) selective laser melting
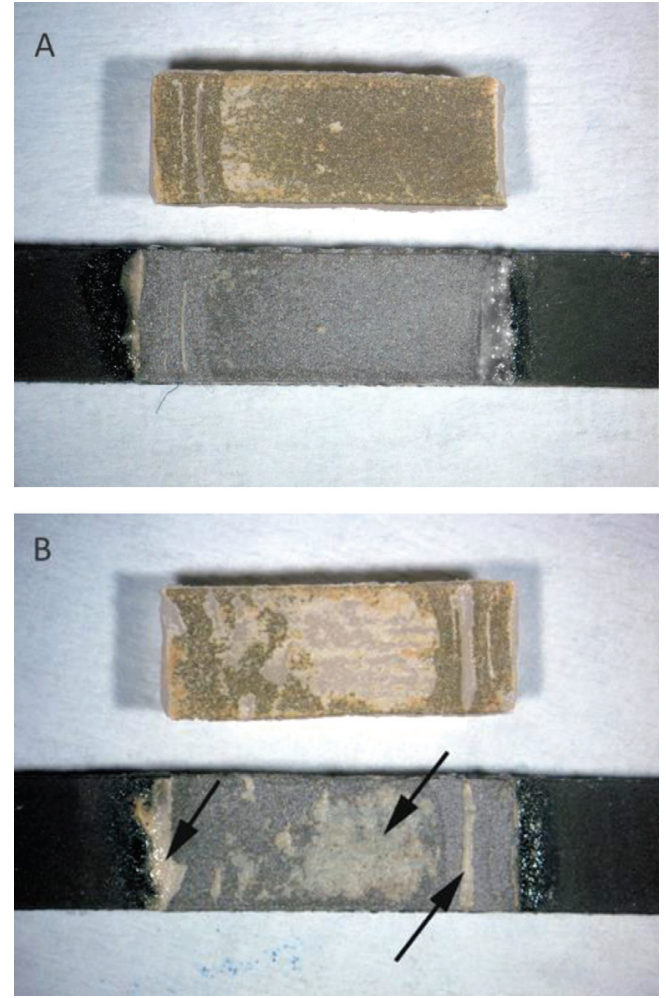

Figure 3: Fracture analysis: a) adhesive mode of failure, b) mixed mode of failure, the arrows point to the porcelain remnants on the Co-Cr surface
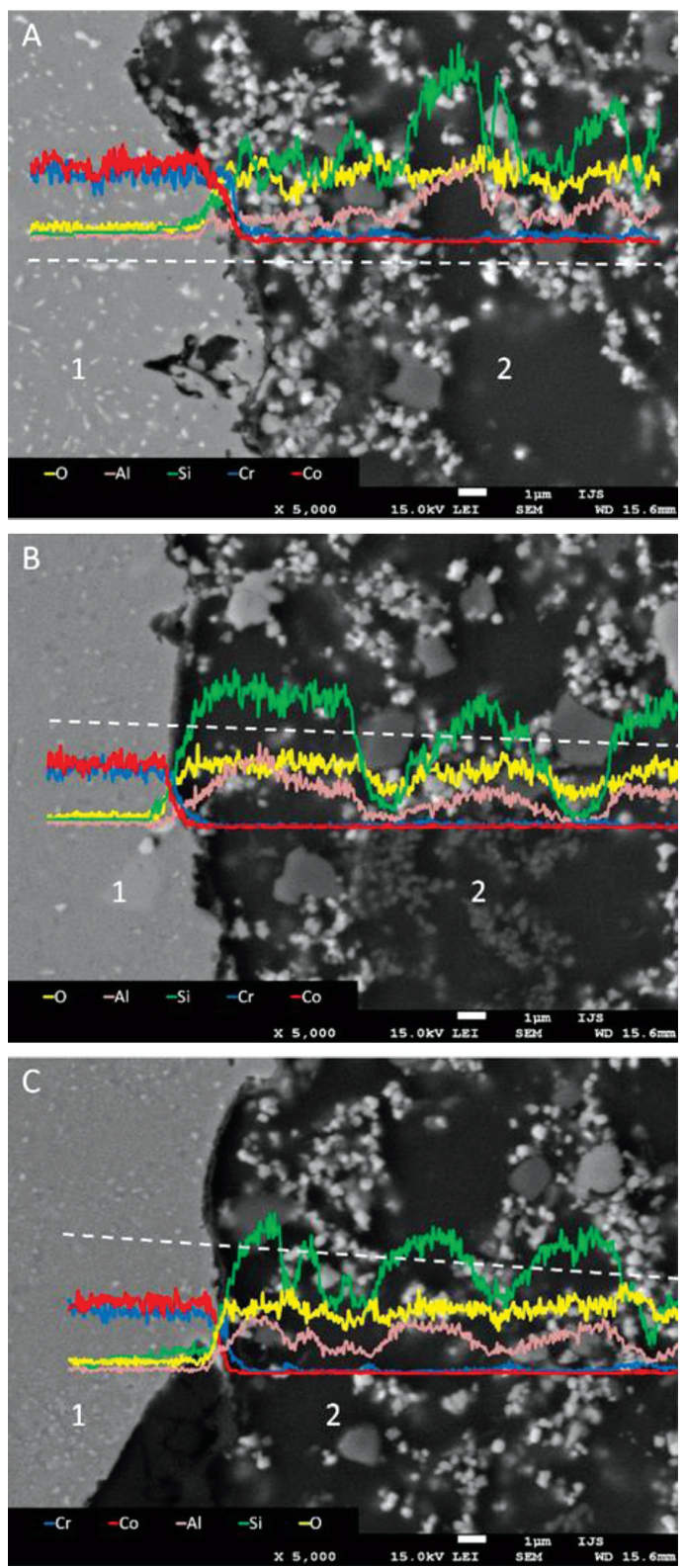

Figure 4: FE-SEM micrographs of the Co-Cr-ceramic interfaces for: a) cast, b) milled, c) selective laser melted specimens. The EDS profiles demonstrate the variation of arbitrary units of intensity (counts per second) of each element in relation to the distance $(\mu \mathrm{m})$ along the scan line (dashed line) - from metal (1) towards the porcelain (2). Each element is presented in a different color. The xand $y$-axes are omitted for the sake of clarity.

mics, while $\mathrm{Si}, \mathrm{O}$ and $\mathrm{Al}$ signals increased progressively. The EDS signals of the main elements comprising the metal and the ceramic counterparts showed sigmoidal intensity vs distance curves on the interface, with certain distortions over the porcelain segment, due to the inclusion of different metal oxides in the dental porcelain.

\section{DISCUSSION}

This study was set up to explore the effects of the applied routes for fabricating $\mathrm{Co}-\mathrm{Cr}$ dental frameworks 
on the metal surface characteristics and on the metalceramic bond strength. The null hypothesis, stating that the varied fabrication of $\mathrm{Co}-\mathrm{Cr}$ would not affect its surface roughness following airborne-particle abrasion, was rejected. Both the contact profilometer and the 3D focus-variation microscopy analyses recorded an increased surface roughness of the SLM substrates, when compared to that of the cast and milled substrates. This could be related to the marked differences in the procedures involved in casting, milling and SLM of metal frameworks. Namely, Co-Cr is exposed to different heating and cooling conditions depending on the fabrication method applied, which results in variations in microstructure and surface characteristics of the alloy. ${ }^{8,18-20,25,26}$ During SLM, the metal powder particles found on the borderline of the laser fusion are partially melted and become loosely attached to the metal substrate. ${ }^{28,29}$ The presence of partially attached particles on the surface of the SLM alloy creates a 'balling' texture that is associated with an increase in the surface roughness. ${ }^{19}$ Thus, the SLM substrates exhibit high roughness originating from the fabrication procedures. It is generally considered that alloy roughness promotes mechanical interlocking between the metal and the porcelain, which is one of the main mechanisms underlying the metal-ceramic bond strength. , $^{90,31}$ Although the pronounced roughness of the SLM alloy did not seem to have resulted in significantly improved metal-ceramic bond strength in the present study, the incidence of mixed fractures in the SLM group, with porcelain remnants on the metal surface, implies better porcelain adherence to SLM Co-Cr relative to that of cast and milled $\mathrm{Co}-\mathrm{Cr}$. On the other hand, the failure-mode analysis for the cast and milled alloys revealed exclusively adhesive modes of failure, with fractures occurring between the metal and the metal oxide/ceramics, thus implying weaker porcelain adherence for these groups. The milled alloy exhibited the lowest surface roughness following airborne-particle abrasion, together with the weakest metal-ceramic bond strength among the tested groups, although no significant difference was recorded for the latter. This could be related to the limited mechanical retention between the porcelain and the relatively smooth surface of the milled Co-Cr. The results of the present study thus indicate that due to variations in the metal roughness, the mechanical bond between the metal and the ceramics can be affected by the varied $\mathrm{Co}-\mathrm{Cr}$ fabrication.

It should be noted, however, that the metal substrates were airborne-particle abraded in the present study. Surface roughening by abrasion with airborne $\mathrm{Al}_{2} \mathrm{O}_{3}$ particles has been widely accepted as a standard operating procedure for bond enhancement in clinical practice..$^{9,32,33}$ It promotes mechanical retention between the metal and the ceramics.9,30,31 Furthermore, airborneparticle abrasion also removes gross surface irregularities and cleans the investment material from the surface of the cast alloys. ${ }^{9,33}$ Although differently processed Co-Cr alloys exhibited somewhat similar surface textures due to the airborne-particle abrasion, the findings of pronounced roughness of the SLM substrates indicate a need for a re-evaluation of the traditional Co-Cr surface conditioning protocols and their adjustment for SLM processed alloys. The pre-existing roughness of the metal framework, originating from the fabrication procedures, ${ }^{19,29,34}$ could modify the effects of airborne-particle abrasion on porcelain bonding. Namely, several studies have shown that the metal-ceramic bond strength does not necessarily show a positive correlation with the roughness of the metal substrate. . $^{30,34,35}$ The high surface roughness of the alloy can inhibit the wetting ability of the porcelain, resulting in a decreased bond strength. . $^{30,36}$ Thus, further studies are necessary to establish the appropriate surface preparation protocols that would allow optimal surface textures of the metal frameworks fabricated by different technologies.

Nevertheless, the SEM/EDS results of the present study recorded good wetting between the porcelain and differently processed $\mathrm{Co}-\mathrm{Cr}$ alloys, together with a comparable distribution of the elements on the interface. The gradual sigmoidal transitions between elements comprising the metal and the porcelain counterparts indicate element diffusion at the interface. Thus, the chemical bond between the metal and the ceramics does not seem to be affected by the varied $\mathrm{Co}-\mathrm{Cr}$ fabrication. This is in agreement with the findings of A. Jabbari et al., ${ }^{8}$ showing that differently processed alloys exhibit variations in microstructure and hardness, but not in the distribution of elements on the metal-ceramic interface.

It should be noted, however, that the increased metal roughness also enlarges the effective area for chemical bonding between the metal and the porcelain. Thus, variations in the strength of the chemical bond should not be excluded. Nevertheless, the bond strength results of the present study showed that the overall strength of the porcelain bond to $\mathrm{Co}-\mathrm{Cr}$ was not influenced by the metal-processing technology applied. This is in agreement with earlier reports. ${ }^{18,20-23,37,38}$ The consistent bond strengths could be related to the comparable oxidation rates of differently processed $\mathrm{Co}-\mathrm{Cr}$ alloys. Namely, J. Li et al. ${ }^{23}$ investigated the microstructure and oxidation characteristics of the cast, milled and SLM Co-Cr alloys and showed that although differences in the microstructure were present, the oxidation rates of differently processed $\mathrm{Co}-\mathrm{Cr}$ alloys were alike.

The recorded porcelain bond strengths to cast, milled and SLM Co-Cr alloys in the present study were well above the minimum ISO 9693-1:2012 recommended value of $25 \mathrm{MPa}$ for metal-ceramic systems, ${ }^{27}$ suggesting that both milled and SLM Co-Cr-ceramic systems can be used in clinical practice as alternatives to the traditional cast Co-Cr-ceramic systems. The clinical studies demonstrate the high long-term reliability of PFM prostheses made of cast $\mathrm{Co}-\mathrm{Cr},{ }^{39}$ although somewhat increased 
susceptibility to porcelain fractures has been reported for the latter in comparison to that of metal-ceramic restorations made of noble alloys. ${ }^{40}$ The long-term effect of the applied route for fabricating metal frameworks on the clinical performance of PFM prostheses is, however, unknown. Further clinical studies are necessary to assess the reliability of CNC milled and SLM Co-Cr-ceramic prostheses.

\section{CONCLUSIONS}

Within the limitations of this study, the following conclusions can be drawn:

The porcelain bond strength to $\mathrm{Co}-\mathrm{Cr}$ is not affected by the metal processing technology applied, such as casting, milling or SLM.

The porcelain bond strengths to cast, milled and SLM Co-Cr alloys are well above the minimal ISO 9693-1:2012 recommended value of $25 \mathrm{MPa}$ for metal-ceramic systems, thus allowing clinical application of SLM Co-Cr in PFM prostheses.

The surface roughness of the $\mathrm{Co}-\mathrm{Cr}$ substrates following airborne-particle abrasion is affected by the metal processing technology applied, such as casting, milling or SLM. Namely, the SLM substrates showing increased roughness relative to that of the cast and milled substrates.

\section{Acknowledgment}

The authors acknowledge the financial support from the Slovenian Research Agency (research core funding Nos. P2-0087 and P2-0050).

\section{REFERENCES}

${ }^{1}$ B. E. Pjetursson, I. Sailer, N. A. Makarov, M. Zwahlen, D. S. Thoma, All-ceramic or metal-ceramic tooth-supported fixed dental prostheses (FDPs), A systematic review of the survival and complication rates. Part II: Multiple-unit FDPs. Dent Mater, 31 (2015) 6, 624-639, doi:10.1016/j.dental.2015.02.013

${ }^{2}$ H. W. Roberts, D. W. Berzins, B. K. Moore, D. G. Charlton, Metal-Ceramic Alloys in Dentistry: A Review. J. Prosthodont Res., 18 (2009) 2, 188-194, doi:10.1111/j.1532-849X.2008.00377.x

${ }^{3}$ D. Y. Kim, J. H. Kim, H. Y. Kim, W. C. Kim, Comparison and evaluation of marginal and internal gaps in cobalt-chromium alloy copings fabricated using subtractive and additive manufacturing. J. Prosthodont Res., 62 (2018) 1, 56-64, doi:10.1016/j.jpor.2017. 05.008

${ }^{4}$ P. Haag, K. Nilner, Questions and answers on titanium-ceramic dental restorative systems: a literature study, Quintessence Int., 38 (2007) 1, 5-13

${ }^{5} \mathrm{R}$. Van Noort, The future of dental devices is digital, Dent. Mater., 28 (2012) 1, 3-12, doi:10.1016/j.dental.2011.10.014

${ }^{6}$ T. F. Alghazzawi, Advancements in CAD/CAM technology: Options for practical implementation, J. Prosthodont Res., 60 (2016) 2, 72-84, doi:10.1016/j.jpor.2016.01.003

${ }^{7}$ J. R. Strub, E. D. Rekow, S. Witkowski, Computer-aided design and fabrication of dental restorations: current systems and future possibilities, J. Am. Dent. Assoc., 137 (2006) 9, 1289-1296
${ }^{8}$ Y. S. A. Jabbari, T. Koutsoukis, X. Barmpagadaki, S. Zinelis, Metallurgical and interfacial characterization of PFM Co-Cr dental alloys fabricated via casting, milling or selective laser melting, Dent. Mater., 30 (2014) 4, 79-88, doi:10.1016/j.dental.2014.01.008

${ }^{9}$ M. J. Reyes, Y. Oshida, C. J. Andres, T. Barco, S. Hovijitra, D. Brown, Titanium-porcelain system, Part III: effects of surface modification on bond strengths, Biomed. Mater. Eng., 11 (2001) 7, 117-136

${ }^{10}$ J. R. Jr. Mackert, E. E. Parry, D. T. Hashinger, C. W. Fairhurst, Measurement of oxide adherence to PFM alloys, J. Dent. Res., 63 (1984) 11, 1335-1240, doi:10.1177/00220345840630111701

${ }^{11}$ B. W. King, H. P. Tripp, W. H. Duckworth, Nature of Adherence of Porcelain Enamels to Metals, J. Am. Ceram. Soc., 42 (1959) 11, 504-525, doi:10.1111/j.1151-2916.1959.tb13567.x

${ }^{12}$ B. H. Li, J. T. Ye, J. K. Liao, P. L. Zhuang, Y. P. Zhang, J. Y. Li, Effect of pretreatments on the metal ceramic bonding strength of a Pd-Ag alloy, J.Dent., 42 (2014) 3, 319-328, doi:10.1016/j.jdent. 2013.11.020

${ }^{13}$ C. Sipahi, M. Özcan, Interfacial shear bond strength between different base metal alloys and five low fusing feldspathic ceramic systems, Dent. Mater. J., 31 (2012) 3, 333-337, doi:10.4012/ dmj.2011-143

${ }^{14}$ S. C. Lopes, V. O. Pagnano, J. M. Rollo, M. B. Leal, O. L. Bezzon, Correlation between metal-ceramic bond strength and coefficient of linear thermal expansion difference, J. Appl. Oral Sci., 17 (2009) 2, 122-128

${ }^{15}$ F. Pitt, M. Ramulu, Influence of grain size and microstructure on oxidation rates in titanium alloy Ti-6Al-4V under superplastic forming conditions, J. Mater.Eng. Perform., 13 (2004) 6, 727-734, doi:10.1361/10599490421394

${ }^{16}$ M. M. A. Vrijhoef, J. M. Van Der Zel, Oxidation of a gold-palladium PFM alloy, J. Oral Rehabil., 15 (1988) 3, 307-312

${ }^{17}$ H. Ohno, O. Miyakawa, K. Watanabe, N. Shiokawa, The structure of oxide formed by high-temperature oxidation of commercial gold alloys for porcelain-metal bonding, J. Dent. Res., 61 (1982) 11, 1255-1261, doi:10.1177/00220345820610111001

${ }^{18}$ B. Henriques, D. Soares, F. S. Silva, Microstructure, hardness, corrosion resistance and porcelain shear bond strength comparison between cast and hot pressed CoCrMo alloy for metal-ceramic dental restorations, J. Mech. Behav. Biomed. Mater., 12 (2012), 83-92, doi:10.1016/j.jmbbm.2012.03.015

${ }^{19}$ E. J. Bae, J. H. Kim, W. C. Kim, H.Y. Kim, Bond and fracture strength of metal-ceramic restorations formed by selective laser sintering, J. Adv. Prosthodont, 6 (2014) 4, 266-271, doi:10.4047/ jap.2014.6.4.266

${ }^{20}$ H. Wang, Q. Feng, N. Li, S. Xu, Evaluation of metal-ceramic bond characteristics of three dental $\mathrm{Co}-\mathrm{Cr}$ alloys prepared with different fabrication techniques, J. Prosthet. Dent., 116 (2016) 6, 916-923, doi:10.1016/j.prosdent.2016.06.002

${ }^{21}$ L. Wu, H. Zhu, X. Gai, Y. Wang, Evaluation of the mechanical properties and porcelain bond strength of cobalt-chromium dental alloy fabricated by selective laser melting, J. Prosthet. Dent., 111 (2014) 1, 51-55, doi:10.1016/j.prosdent.2013.09.011

${ }^{22}$ N. Xiang, X. Z. Xin, J. Chen, B. Wei, Metal-ceramic bond strength of Co-Cr alloy fabricated by selective laser melting, J. Dent., 40 (2012) 6, 453-457, doi:10.1016/j.jdent.2012.02.006

${ }^{23}$ J. Li, C. Chen, J. Liao, L. Liu, X. Ye, S. Lin, J. Ye, Bond strengths of porcelain to cobalt-chromium alloys made by casting, milling, and selective laser melting, J. Prosthet. Dent., 118 (2017) 1, 69-75, doi:10.1016/j.prosdent.2016.11.001

${ }^{24}$ K. C. Li, L. Tran, D. J. Prior, J. N. Waddell, M. V. Swain, Porcelain bonding to novel Co-Cr alloys: Influence of interfacial reactions on phase stability, plasticity and adhesion, Dent. Mater., 32 (2016) 12, 1504-1512, doi:10.1016/j.dental.2016.09.008

${ }^{25}$ T. Koutsoukis, S. Zinelis, G. Eliades, K. Al-Wazzan, M. A. Rifaiy, Y. S. A. Jabbari, Selective laser melting technique of $\mathrm{Co}-\mathrm{Cr}$ dental alloys: A review of structure and properties and comparative analysis 


\section{ANTANASOVA et al.: THE BOND STRENGTH OF DENTAL PORCELAIN TO COBALT-CHROMIUM ...}

with other available techniques, J. Prosthodont, 24 (2015) 4, 303-312, doi:10.1111/jopr.12268

${ }^{26}$ B. Qian, K. Saeidi, L. Kvetkova, F. Lofaj, C. Xiao, Z. Shen, Defects-tolerant Co-Cr-Mo dental alloys prepared by selective laser melting, Dent. Mater., 31 (2015) 12, 1435-1444, doi:10.1016/ j.dental.2015.09.003

${ }^{27}$ ISO 9693-1:2012 - Dentistry-Compatibility testing-Part 1: Metalceramic systems. ISO Committee, Geneve

${ }^{28}$ J. Vaithilingam, E. Prina, R. D. Goodridge, R. J. M. Hague, S. Edmondson, F. R. A. J. Rose, S. D. R. Christie, Surface chemistry of Ti6Al4V components fabricated using selective laser melting for biomedical applications, Mater. Sci. Eng. C, 67 (2016), 294-303, doi:10.1016/j.msec.2016.05.054

${ }^{29}$ I. Yadroitsev, I. Smurov, Surface Morphology in Selective Laser Melting of Metal Powders, Physics Procedia, 12 (2011), 264-270, doi:10.1016/j.phpro.2011.03.034

${ }^{30}$ M. A. Carpenter, R. J. Goodkind, Effect of varying surface texture on bond strength of one semiprecious and one nonprecious ceramo-alloy, J. Prosthet. Dent., 42 (1979), 86-95

${ }^{31}$ F. J. Knap, G. Ryge, Study of bond strength of dental porcelain fused to metal, J. Dent. Res., 45 (1966) 4, 1047-1051, doi:10.1177/ 00220345660450040501

${ }^{32}$ M. Antanasova, P. Jevnikar, Bonding of Dental Ceramics to Titanium: Processing and Conditioning Aspects, Curr Oral Health Rep, 3 (2016) 3, 234-243, doi:10.1007/s40496-016-0107-x

${ }^{33}$ I. Al Hussaini, K. A. Al Wazzan, Effect of surface treatment on bond strength of low-fusing porcelain to commercially pure titanium, J. Prosthet. Dent., 94 (2005) 4, 350-356, doi:10.1016/j.prosdent. 2005.07.007
${ }^{34}$ M. Antanasova, A. Kocjan, J. Kovač, B. Žužek, P. Jevnikar, Influence of thermo-mechanical cycling on porcelain bonding to cobalt-chromium and titanium dental alloys fabricated by casting, milling, and selective laser melting, J. Prosthodont. Res., 62 (2018) 2, 184-194, doi:10.1016/j.jpor.2017.08.007

${ }^{35} \mathrm{C}$. A. Mohsen, Effect of surface roughness and thermal cycling on bond strength of C.P. titanium and Ti-6Al-4V alloy to ceramic, J. Prosthodont. Res., 56 (2012) 3, 204-209, doi:10.1016/j.jpor.2011. 10.001

${ }^{36}$ M. Kelly, K. Asgar, W. J. O'Brien, Tensile strength determination of the interface between porcelain fused to gold, J. Biomed. Mater. Res., 3 (1969) 3, 403-408, doi:10.1002/jbm.820030302

${ }^{37}$ T. Akova, Y. Ucar, A. Tukay, M. C. Balkaya, W. A. Brantley, Comparison of the bond strength of laser-sintered and cast base metal dental alloys to porcelain, Dent. Mater., 24 (2008) 10, 1400-1404, doi:10.1016/j.dental.2008.03.001

${ }^{38}$ J. Serra-Prat, J. Cano-Batalla, J. Cabratosa-Termes, O. FiguerasAlvarez, Adhesion of dental porcelain to cast, milled, and laser-sintered cobalt-chromium alloys: shear bond strength and sensitivity to thermocycling, J. Prosthet. Dent., 112 (2014) 3, 600-605, doi:10.1016/j.prosdent.2014.01.004

${ }^{39}$ A. Eliasson, C. F. Arnelund, A. Johansson, A clinical evaluation of cobaltchromium metal-ceramic fixed partial dentures and crowns: A three- to seven-year retrospective study, J. Prosthet. Dent., 98 (2007) 1, 6-16, doi:10.1016/S0022-3913(07)60032-8

${ }^{40}$ A. Mikeli, K. W. Boening, B. Lisske, Ceramic Defects in MetalCeramic Fixed Dental Prostheses Made from $\mathrm{Co}-\mathrm{Cr}$ and $\mathrm{Au}-\mathrm{Pt}$ Alloys: A Retrospective Study, Int. J. Prosthodont., 28 (2015) 5, 487-489, doi:10.11607/ijp.4234 